\title{
Temporal variations in discharge rate and component characteristics of tephra-fall deposits during the 2014-2015 eruption of Nakadake first crater, Aso Volcano, Japan
}

\author{
Yasuo Miyabuchi ${ }^{1,2^{*}}$ and Chihoko Hara ${ }^{3}$
}

\begin{abstract}
The 2014-2015 eruption of the Nakadake first crater at Aso Volcano in southwestern Japan was characterized by continuous ash emissions and intermittent strombolian eruptions. In this paper, we present the distribution, discharged mass, and components of tephra-fall deposits to examine the sequence of activities. We installed 21 ash samplers around the crater (SW crater rim to $9 \mathrm{~km}$ in all directions) and calculated the mass of ash-fall deposits based on 28 isomass maps. From November 25, 2014, to the end of January 2015, the cumulative erupted mass increased at a high discharge rate $\left(2.2 \times 10^{4}\right.$ tons/day). After February 2015 , the cumulative erupted mass decreased to a low rate of $0.6 \times 10^{4}$ tons/day, although this rate rose slightly in March and late April 2015. The 2014-2015 tephra-fall deposits consisted of glass shards, crystal, and lithic grains. In the November 25-27, 2014 ash-fall deposits, lithic fragments, which are interpreted to be derived from lavas or pyroclasts of previous eruptions, were dominant (59-68\%). Thereafter, the proportion of glass shards, which are probably juvenile materials of newly ascending magma, gradually increased with time, and the December 21-23, 2014 ash contained abundant glass grains (63\%). The proportions of glass shards ranged from 29 to 50\% until February 25, 2015. Subsequently, they decreased with time and reached 14\% on March 17. Afterward, the proportions increased again prior to April 27 and ranged between 20 and 30\% in May 2015. The total erupted tephra mass from the November 2014-May 2015 activity of Nakadake first crater was $2.1 \times 10^{6}$ tons $\left(1.2 \times 10^{4}\right.$ tons/day), which was less than the tephra deposits of previous activities that have occurred within the past few decades.
\end{abstract}

Keywords: Erupted mass, Component characteristics, Tephra-fall deposit, Small-scale eruption, Nakadake first crater, Aso Volcano

\section{Introduction}

Small eruptions including gentle ash emissions, strombolian, and vulcanian eruptions frequently occur at basaltic to andesitic volcanoes worldwide (e.g., Ono et al. 1995; Taddeucci et al. 2002; Andronico et al. 2008; D'Oriano et al. 2011; Iguchi et al. 2013). Although these activities rarely cause fatalities, they produce fallout tephra deposits continuously or repeatedly for a long time. Local

\footnotetext{
*Correspondence: miyabuchi@gmail.com

${ }^{1}$ Faculty of Advanced Science and Technology, Kumamoto University,

Kurokami 2-40-1, Chuo-ku, Kumamoto 860-8555, Japan

Full list of author information is available at the end of the article
}

inhabitants, infrastructure, and agriculture in the surrounding areas are greatly affected by these activities. It is therefore very important to clarify the distribution and components of the tephra-fall deposits to estimate their effects around the volcanoes and plan hazard mitigation. Many previous tephra studies have focused mainly on medium- to large-scale eruptions (VEI $>2$ ), including plinian and sub-plinian eruptions (e.g., Fierstein and Hildreth 1992; Miyabuchi et al. 2013). In contrast, detailed geological and petrological studies on small-scale eruptions $(\mathrm{VEI}<2)$ and related deposits are limited by the poor nature of such eruptive deposits because they are rarely well preserved after the eruptions due to their 
paucity and fine-grained nature. Obtaining information on the mass and component characteristics of erupted materials is fundamental to understanding the sequence of events and mechanisms involved in these eruptions. However, few continuous observations of ash-fall deposits during one active period lasting a few months to a few years to elucidate temporal variations in the masses and components have been performed, except for some examples at Sakurajima Volcano (Nakamura 2002; Shimano et al. 2013; Miwa et al. 2013; Oishi et al. 2018).

The Nakadake first crater at Aso Volcano, which is one of the most active volcanoes in Japan, began a series of magmatic eruptions on November 25, 2014, and continued to May 3, 2015. The eruptive activity was dominated by continuous gentle ash emissions and intermittent strombolian eruptions. The most typical volcanic activity of the Nakadake first crater within the last few decades has been the continuous fallout of black sandy ash derived from the solid glassy top of a magma column (Ono et al. 1995). This activity, called an ash eruption, has continued for more than 10,000 years (Ono et al. 1995; Miyabuchi 2009), and the eruptive deposits distributed around the volcano are composed mainly of fine-grained ash-fall deposits rather than coarse-grained scoria-fall deposits. This fact indicates that most of the magma beneath the Nakadake Volcano has been discharged as fine-grained ash due to small-scale eruptive activity that has lasted for at least 10,000 years.

We undertook fieldwork in and around the Aso caldera from November 2014 to May 2015, to examine the distributions and characteristics of tephra-fall deposits associated with the 2014-2015 eruptions of the Nakadake first crater. We present here the distributions, discharged masses, and components of the related deposits, and discuss the sequence and characteristics of the series of eruptions.

\section{Geological setting}

Nakadake Volcano is the only active central cone in the Aso caldera, central Kyushu. A composite volcano of basaltic andesite to basalt, Nakadake became active from ca. 22-21 ka (Miyabuchi et al. 2004) and consists of an old edifice (agglutinate and lava), a young edifice (pyroclasts and lava), and a still younger pyroclastic cone (Ono and Watanabe 1985). The old volcanic edifice is the main cone of Nakadake Volcano, rising approximately $900 \mathrm{~m}$ from the caldera floor. The upper part of the edifice is a complex cone made largely of welded spatter, with subordinate amounts of other pyroclastic materials. The lower part of the edifice is composed mainly of lava flows. Recent tephrochronological studies (Miyabuchi et al. 2003, 2004; Miyabuchi 2009) indicate that most of the edifice was constructed at ca. 22-21 ka. Thereafter, the western half of the upper edifice was destroyed by a northwestward-directed horseshoe-like collapse, leaving a 250-m-high collapsed crater wall (Ono et al. 1995). The young volcanic edifice is believed to have been formed during the Holocene, and the youngest pyroclastic cone subsequently arose from inside the young edifice (Ono and Watanabe 1985). The active crater of Nakadake Volcano, formed in the youngest pyroclastic cone, is a composite of seven small craters aligned N-S. Only the northernmost crater (first crater) has been active in the past 80 years, although some others were active before the 1933 eruption (Fukuoka District Meteorological Observatory 1965).

The first crater of Nakadake is occupied by a hot, hyperacidic ( $\mathrm{pH} 0.43$ ) crater lake during its calm periods (Miyabuchi and Terada 2009; Ohsawa et al. 2010; Terada et al. 2012) and has maintained a high heat discharge rate of approximately $220 \mathrm{MW}$ (Terada et al. 2008). During active periods, volcanic activity of Nakadake first crater is characterized by gentle release of black sandy ash (ash eruption; Ono et al. 1995). During more active periods, strombolian eruptions have scattered red-hot scoriaceous clasts around the vent. Moreover, the phreatic or phreatomagmatic eruptions that occurred in June 1958, September 1979, April 1990, and September 2015, have ejected coarse lithic blocks that are capable of causing human casualties near the crater as well as generating small, low-temperature pyroclastic density currents (Taneda et al. 1959; Ono et al. 1982; Ikebe et al. 2008; Miyabuchi et al. 2018).

\section{Outline of the 2014-2015 activity}

Following the 1988-1995 major activity that included ash, strombolian, and phreatomagmatic eruptions (Ikebe et al. 2008), surface unrest of the Nakadake first crater had been mostly mild, except for several small ash emissions through the hyperacid crater lake in 2003, 2004, 2005, and 2008 (Miyabuchi et al. 2008; Miyabuchi and Ikebe 2008). The crater lake began to get smaller, starting on April 2013, and the surface ratio of the lake water to the crater bottom fell to $<10 \%$ after December 2013 . Then, small ash emissions occurred from the Nakadake first crater between January 13 and February 19, 2014 (Fukuoka District Meteorological Observatory 2015; Ichimura et al. 2018). Subsequently, the crater bottom dried up on July 12, and a vent near the center of the crater has been incandescent since July 28, 2014. A minor eruption that occurred on August 30, 2014, prompted the Fukuoka District Meteorological Observatory (FDMO) of the Japan Meteorological Agency (JMA) to issue, on the same day, a volcanic warning (near-crater warning) changing the volcanic alert level from level 1 (normal condition) to level 2 (do not approach the crater). 
The Nakadake first crater began a series of magmatic eruptions on November 25, 2014. Relatively, active eruptive events dominated by gray ash plumes $(<1500 \mathrm{~m}$ above the crater rim) continued until May 3, 2015 (Fig. 1). Strombolian eruptions intermittently scattering scoriaceous bombs (up to $300 \mathrm{~m}$ in height), appeared immediately after the onset of eruptions (Yokoo and Miyabuchi 2015), although they occurred a few months after the beginning of the activity during previous activity (Ikebe et al. 2008). These activities were restricted to vent 141 (designation assigned by the JMA), which was located near the center of the Nakadake first crater. A pyroclastic cone was formed around this vent by the deposition of large amounts of ash and scoria (Yokoo and Miyabuchi 2015). The southern half of the 141 pyroclastic cone has disappeared, probably due to a collapse caused by an earthquake that was felt on May 3 (Fukuoka District Meteorological Observatory 2016). Afterward, a small amount of hot water reentered the 141 pyroclastic cone on June 10, 2015, followed by small eruptions on August 8 and September 3, 2015. The maximum temperature of the water ranged from 80 to $90{ }^{\circ} \mathrm{C}$, and several hightemperature areas of $100-400{ }^{\circ} \mathrm{C}$ were observed inside the cone of vent 141 (Fukuoka District Meteorological Observatory 2016). Crustal deformation related to the inflation of the magma reservoir was observed from July 2015 by GPS observation (Ohkura 2018).

On September 14, 2015, a phreatomagmatic eruption generated a ballistic ejecta apron and pyroclastic density currents around the crater. The total discharged mass of the eruption was estimated at $7.9 \times 10^{4}$ tons (Miyabuchi et al. 2018). Because of this eruption, the FDMO issued a volcanic warning changing the volcanic alert level from level 2 (do not approach the crater) to level 3 (do not approach the volcano). After the September 14 eruption, intermittent small eruptions produced ash falls. On October 23, two explosive eruptions took place at 02:59 and 06:02 $(=\mathrm{UTC}+9)$ and their ash plumes rose $1400 \mathrm{~m}$ and $1600 \mathrm{~m}$ above the crater rim, respectively (Fukuoka District Meteorological Observatory 2016). Both eruptions were accompanied by a ballistic fallout, resulting in severe damage to the crater rim area.

\section{Methods}

We first undertook fieldwork in and around the Aso caldera from November 26 to 29, 2014, to examine tephra deposits associated with the 2014-2015 activity of Nakadake first crater. Ash samples were obtained from the surfaces of man-made constructions including roads and concrete floors at 57 sites, and the area from which
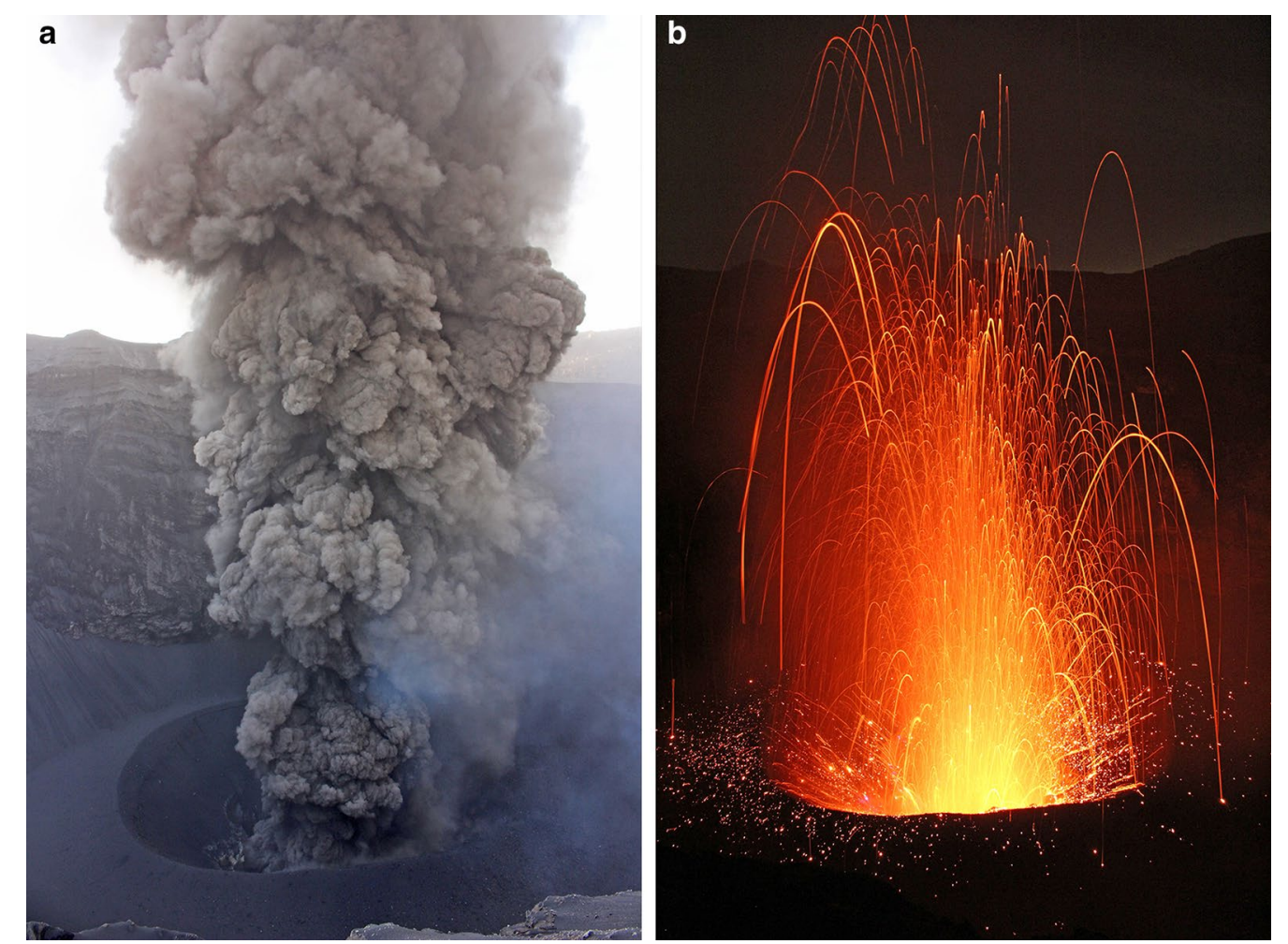

Fig. 1 Photographs of typical eruption styles during the 2014-2015 magmatic activity of Nakadake first crater. a Ash-emitting activity from vent 141 in the daytime of January 13, 2015. b Strombolian eruption during the night of January 13, 2015 
the samples were collected was measured. Subsequently, we installed 21 ash samplers (polyethylene bucket; $25 \mathrm{~cm}$ across and deep, $491 \mathrm{~cm}^{2}$ in area; $2.5 \mathrm{~kg}$ weight inside) around the Nakadake first crater on December $2-16,2014$, to separate new deposits from the previous tephra-fall deposits. The most proximal site was the southwestern rim of the Nakadake first crater, and the most distant site was approximately $9 \mathrm{~km}$ ENE of the crater (Fig. 2). The sampling interval ranged from one to 15 days (averaging about once a week). The samples were dried, and their masses were measured, and then, weight $/ \mathrm{m}^{2}\left(\mathrm{~g} / \mathrm{m}^{2}\right)$ was calculated for each sampling point. During some periods until February 2, 2015, we used ash weight data obtained by JMA (5 sites), Kumamoto Prefectural Government (10 sites), Aso City Office (3 sites), and Takamori Town Office (8 sites). Isomass distribution maps were drawn, based on the weight $/ \mathrm{m}^{2}$ values at the sampling points in each sampling period. The discharged mass calculation was performed for each period, using the method described in the following section.

Samples of the 2014-2015 ash-fall deposits were examined under a polarizing microscope to clarify their components. The samples were washed ultrasonically for approximately $10 \mathrm{~min}$ and dry-sieved. Ash grains in the fraction of $3-2 \phi(0.125-0.25 \mathrm{~mm})$ were set in an epoxy resin to be fixed onto glass slides. Double-polished thin sections of the samples were then prepared for examination. The components of ash-fall deposits are confined to observations of ash grains within the 3-2 $\phi$ fraction. This is because components of fractions coarser than 2




$\phi$ to $-1 \phi(0.25-2 \mathrm{~mm})$ are almost identical to that of 3-2 $\phi$. This is true in the case of the September 14, 2015 Nakadake phreatomagmatic eruption deposit (Miyabuchi et al. 2018). The proportions of components were determined by counting at least 200 grains in each thin section. Detailed textural observation of glass shards included in the 2014-2015 ash-fall deposits was also made using a scanning electron microscope (SEM; Hitachi TM-1000).

\section{Results}

\section{Distributions of ash-fall deposits}

We obtained 28 isomass maps during the November 2014-May 2015 activity of Nakadake first crater (Additional file 1). According to the variations of wind direction during the sampling periods (1-15 days; average 6 days), ash-fall deposits were distributed around the crater with a main axis and a few minor axes. Most main dispersal axes were oriented in the east to south direction (Fig. 3a) because ash plumes were dispersed mainly by the northwesterly winter to spring winds. Although the November 2014-May 2015 ash-fall deposits were mostly observed inside and east of the Aso caldera, the December 9-11, 2014 ash was dispersed southwestward throughout an area extending $20 \mathrm{~km}$ from the Nakadake first crater (Fig. 3b). Ash deposition areas of more than $100 \mathrm{~g} / \mathrm{m}^{2}$ during most sampling periods were restricted inside the Aso caldera, but during two periods (December 23, 2014-January 7, 2015 and January 7-13, 2015), the areas extended $15-20 \mathrm{~km}$ southeast of the crater (Additional file 1).

\section{Temporal variation in tephra discharge rate}

The mass estimates of the ash-fall deposits were calculated from the 28 isomass maps (Additional file 2). For example, we calculated the total eruptive mass of the November 25-29, 2014 ash-fall deposit using the following method: Plotting their values on a distribution map, eleven isomasses $(30,000,20,000,10,000,5000$, $1000,500,200,100,50,20$, and $10 \mathrm{~g} / \mathrm{m}^{2}$ ) were delineated (Fig. 3a). The relation between the area enclosed by each isomass and the mass is shown in Fig. 4. In the proximal area where the ash deposit was more than $30 \mathrm{~kg} / \mathrm{m}^{2}$, we extrapolated the straight line that connects $20 \mathrm{~kg} / \mathrm{m}^{2}$ with $30 \mathrm{~kg} / \mathrm{m}^{2}$ to the area of the source vent (approximately $10 \mathrm{~m}$ in diameter). This type of mass calculation was not performed in distal areas where the ash deposit was less than $10 \mathrm{~g} / \mathrm{m}^{2}$. The relation between mass and area was divided into 11 sections, and the mass in each section

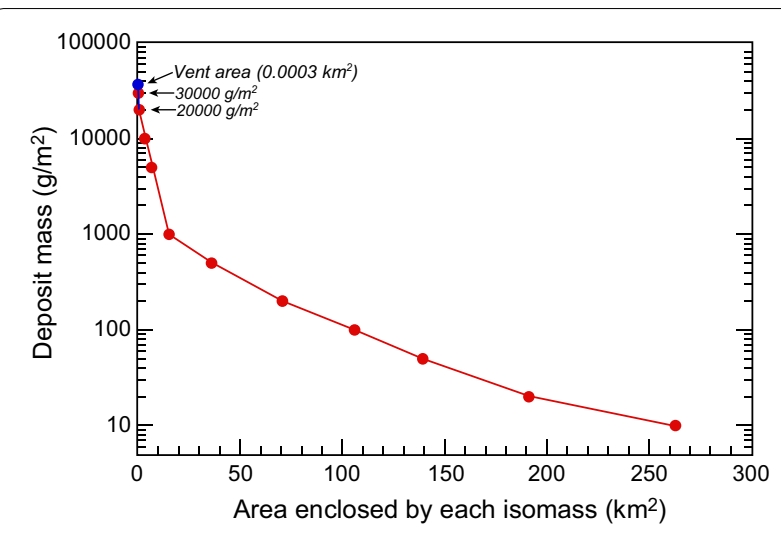

Fig. 4 Relation between area $\left(\mathrm{km}^{2}\right)$ and mass $\left(\mathrm{g} / \mathrm{m}^{2}\right)$ of the November 25-29, 2014 ash-fall deposit from the Nakadake first crater

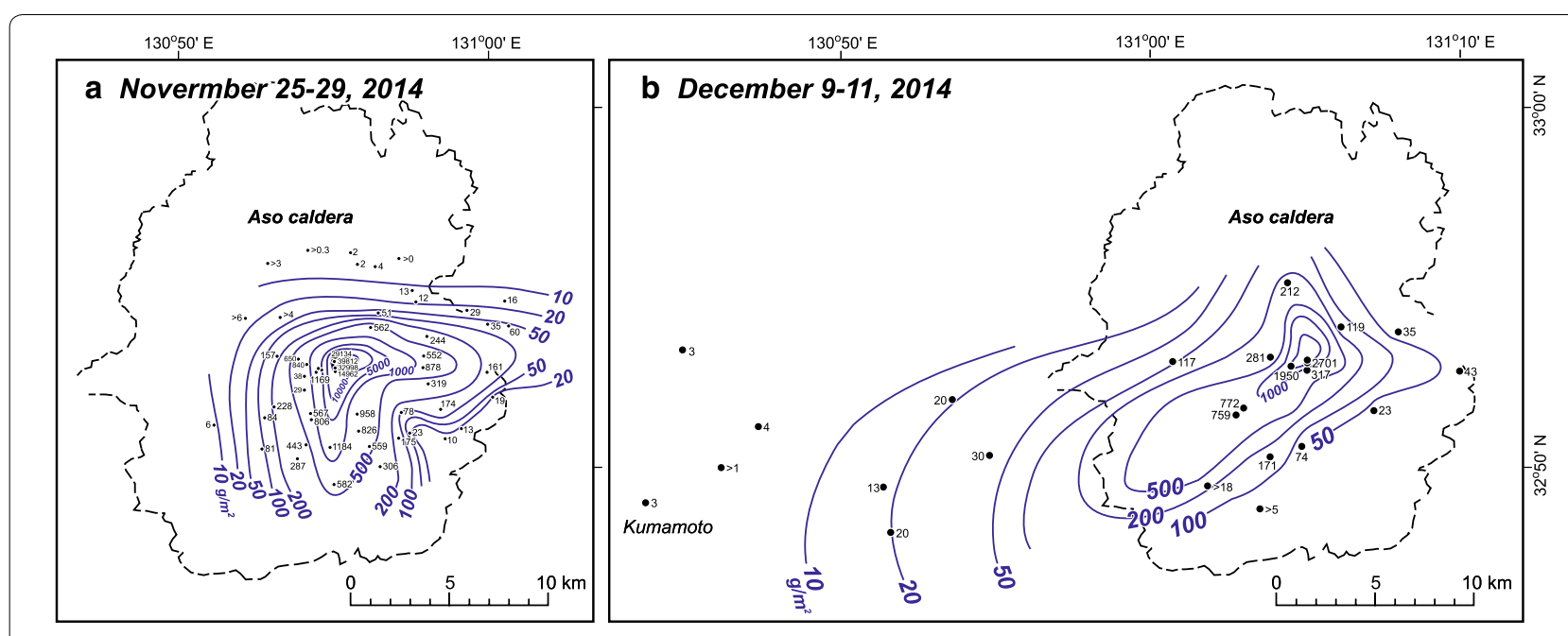

Fig. 3 Distribution maps of the November 25-29, 2014 ash-fall deposit (a) and the December 9-11, 2014 ash-fall deposit (b) 
was calculated by integration. This method indicates that the total mass of the ash-fall deposit was about $1.5 \times 10^{5}$ tons, which corresponds to $3.7 \times 10^{4}$ tons/day.

Temporal variation in the mass of tephra discharged from November 25, 2014, to May 25, 2015, is shown in Table 1 and Fig. 5b. Because the sampling intervals differed between periods (1-15 days), the discharged mass data in the figure are denoted as discharge rates (tons/ day) which are divided by each sampling period (days).

The tephra discharge rate during the first 4 days after the onset of eruption (November 25-29, 2014) was estimated at about $3.7 \times 10^{4}$ tons/day, which was the largest rate during the November 2014-May 2015 activity. Subsequently, the rates fluctuated repeatedly and ranged

Table 1 Mass of tephra discharged during the November 2014-May 2015 activity of Nakadake first crater

\begin{tabular}{|c|c|c|c|}
\hline Period & $\begin{array}{l}\text { Sampling } \\
\text { interval } \\
\text { (days) }\end{array}$ & $\begin{array}{l}\text { Total discharged } \\
\text { mass (x } 10^{4} \text { ton) }\end{array}$ & $\begin{array}{l}\text { Discharge rate } \\
\left(\times 10^{4} \text { ton/day) }\right.\end{array}$ \\
\hline Nov 25-29, 2014 & 4 & 14.9 & 3.7 \\
\hline $\begin{array}{l}\text { Nov 29-Dec 2, } \\
2014\end{array}$ & 3 & 6.6 & 2.2 \\
\hline Dec 2-8, 2014 & 6 & 1.9 & 0.3 \\
\hline Dec 8-9, 2014 & 1 & 2.9 & 2.9 \\
\hline Dec 9-11,2014 & 2 & 7.0 & 3.5 \\
\hline Dec 11-15, 2014 & 4 & 8.4 & 2.1 \\
\hline Dec 15-17, 2014 & 2 & 4.4 & 2.2 \\
\hline Dec 17-23, 2014 & 6 & 6.0 & 1.0 \\
\hline $\begin{array}{l}\text { Dec } 23,2014-J a n \\
\quad 7,2015\end{array}$ & 15 & 38.9 & 2.6 \\
\hline Jan 7-13, 2015 & 6 & 14.3 & 2.4 \\
\hline Jan 13-20, 2015 & 7 & 18.4 & 2.6 \\
\hline $\operatorname{Jan} 20-29,2015$ & 9 & 19.1 & 2.1 \\
\hline Jan 29-Feb 2, 2015 & 4 & 8.1 & 2.0 \\
\hline Feb 2-9, 2015 & 7 & 6.9 & 1.0 \\
\hline Feb 9-16, 2015 & 7 & 3.3 & 0.5 \\
\hline Feb 16-25, 2015 & 9 & 2.7 & 0.3 \\
\hline Feb 25-Mar 2, 2015 & 5 & 3.6 & 0.7 \\
\hline Mar 2-9, 2015 & 7 & 7.1 & 1.0 \\
\hline Mar 9-17, 2015 & 8 & 5.6 & 0.7 \\
\hline Mar 17-23, 2015 & 6 & 6.6 & 1.1 \\
\hline Mar 23-31, 2015 & 8 & 1.8 & 0.2 \\
\hline $\begin{array}{l}\text { Mar 31-Apr 15, } \\
2015\end{array}$ & 15 & 2.5 & 0.2 \\
\hline Apr 15-21, 2015 & 6 & 1.2 & 0.2 \\
\hline Apr 21-27, 2015 & 6 & 8.9 & 1.5 \\
\hline Apr 27-May 4, 2015 & 7 & 10.1 & 1.4 \\
\hline May 4-11, 2015 & 7 & 0.6 & 0.1 \\
\hline May 11-19, 2015 & 8 & 1.4 & 0.2 \\
\hline May 19-25, 2015 & 6 & 0.3 & 0.0 \\
\hline
\end{tabular}

between $2.0 \times 10^{4}$ and $2.5 \times 10^{4}$ tons/day until the end of January 2015. After February 2, the tephra discharge rates tended to decrease to about $0.3 \times 10^{4}$ tons/day in the period of February 16-25. The period of February 25-March 23 displayed intermediate rates ranging from $0.7 \times 10^{4}$ to $1.1 \times 10^{4}$ tons/day, and the period of March 23-April 21 showed small rates of around $0.2 \times 10^{4}$ tons/day, which were the smallest rates observed during the whole activity. Although the rate increased again to $1.4 \times 10^{4}$ tons/day in the period of April 21-May 4, it abruptly decreased to less than $0.1 \times 10^{4}$ tons/day after a collapse accompanied by an earthquake that was felt on May 3, 2015.

Figure $5 \mathrm{~b}$ also displays the cumulative erupted mass of ash-fall deposits from the November 2014-May 2015 eruptive activity. From November 25, 2014, to the end of January 2015, the cumulative mass increased to a high discharge rate $\left(2.2 \times 10^{4}\right.$ tons/day). After February 2015 , it decreased to a low rate $\left(0.6 \times 10^{4}\right.$ tons/day $)$ although the rates slightly rose in March and late April 2015. The cumulative eruptive mass of ash-fall deposits reached about $2.1 \times 10^{6}$ tons until the end of May 2015 (Fig. 5b). The cumulative mass was estimated based on our ash sampling data around the Nakadake first crater, and the value does not include thick tephra deposits that form the 141 cone inside the crater. The size of the cone reached 120-130 $\mathrm{m}$ in rim diameter (vent ca. $50 \mathrm{~m}$ across) and $30 \mathrm{~m}$ in height by the end of March 2015 (Yokoo and Miyabuchi 2015). The volume of the cone including crater floor deposit was $5.0 \times 10^{5} \mathrm{~m}^{3}$, giving a mass of $6.0 \times 10^{5}$ tons assuming a bulk density of $1.2 \mathrm{~g} /$ $\mathrm{cm}^{3}$ for the Nakadake ash (Watanabe 1991). Therefore, the total erupted mass from November 2014 to May 2015 was $2.7 \times 10^{6}$ tons.

\section{Component characteristics of ash-fall deposits}

The polarizing microscope observations revealed that all samples of the November 2014-May 2015 ash-fall deposits from Nakadake first crater consisted of glass shards, crystal, and lithic grains (Fig. 6A). The glass shards were divided by color into transparent, pale brown, brown, and black glasses (Fig. 6A). They were also separated by their shapes into block, scoria, and fluidal type particles (Fig. 6B-I), and the blocky glasses displayed varying degrees of vesiculation. The crystals were single phenocrysts of plagioclase, olivine and clinopyroxene. Some phenocrysts had adhering phenocrysts of a different type and/or glassy fragments. Lithic fragments were divided by color into black, brown, pale brown and translucent grains.

In the November 25-27, 2014 ash-fall deposits, lithic fragments were dominant with proportions ranging from 59 to $68 \%$ (Figs. 5c, 7a). They were moderately to 


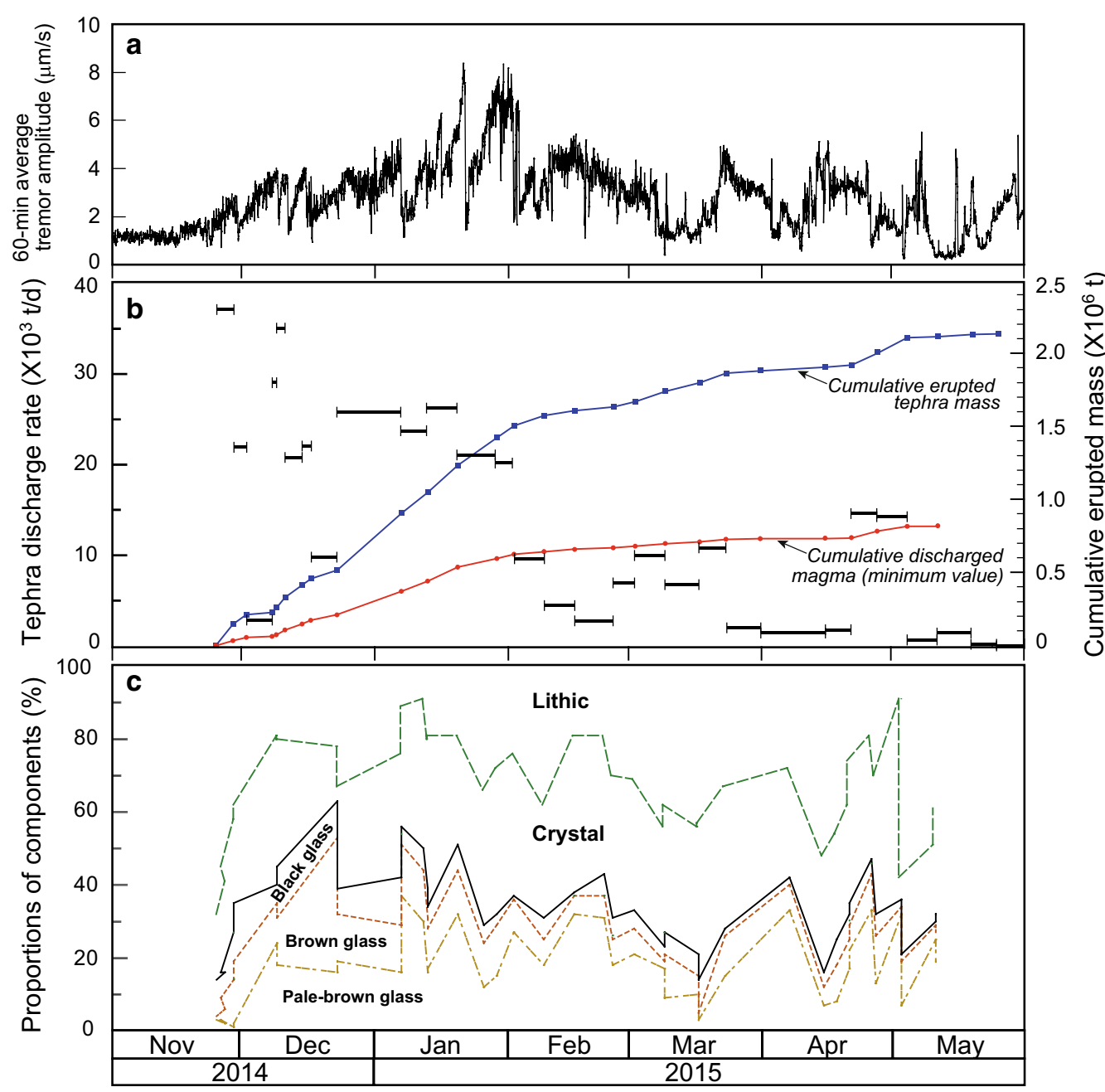

Fig. 5 Temporal variations in 60-min average amplitude of volcanic tremor (a), tephra discharge rate, cumulative erupted mass (b) and proportion of ash components (c). The volcanic tremor (N-S component) was observed at about $0.7 \mathrm{~km}$ WNW of the Nakadake first crater by the Japan Meteorological Agency (Fukuoka District Meteorological Observatory 2016). The cumulative discharged magma was estimated based on proportions of glass shards

highly crystalized and showed varying degrees of alteration. Therefore, we interpret these to be derived from lavas or pyroclasts of previous eruptions. In contrast, the proportions of glass shards in the November 25-27, 2014 ash ranged from 14 to $16 \%$. After November 27, the proportions of glass particles gradually increased with time, and the December 21-23, 2014 ash contained abundant glass grains (63\%). The proportions of glass shards ranged from 29 to 50\% until February 25, 2015. Subsequently, they tended to decrease with time and reached $14 \%$ on March 17. Afterward, the proportions increased again prior to April 27 and ranged between 20 and 30\% in May 2015 (Fig. 7a).

The glass shards within the November 25-29, 2014 ashfall deposits were composed mainly of black-to-brown glass, and thereafter, the proportions of pale brown glass increased with time, comprising $37 \%$ of the glass fraction on January 7, 2015 (Fig. 7a). Pale brown glass shards were dominant from mid-January to May 2015, except for the March 9 and 17, April 15-18, and May 3 ash-fall deposits which were rich in black to brown types of glass $(>50 \%)$.

Overall, poorly to moderately vesiculated blocky glass shards were dominant in the glass fraction from November 2014 to May 2015 (Fig. 7b). In the initial stage, scoria-type glass grains were abundant in the period of November 27-29, and well-vesiculated blocky glass shards were predominant in the December 9 ash-fall deposit. Thereafter, the proportions of moderately to well-vesiculated blocky glass grains tended to be between 20 and $30 \%$ of the glass fraction. In the late stage, the 



Fig. 6 Polarizing microscope photographs $(\mathbf{A}-\mathbf{G})$ and secondary electron micrographs (H-I) of glass shards included in the $2014-2015$ ash-fall deposits. A Glass shards and lithic grains in the December 9-11, 2014 ash. BkG: black glass, BrG: brown glass, C: crystal, L: lithic, PBG: pale brown glass. B Poorly vesiculated blocky glass shard in the December 9-11, 2014 ash. C Vesiculated blocky glass shard in the December 9-11, 2014 ash. D Well-vesiculated blocky glass shard in the December 21-23, 2014 ash. E Scoria-type glass in the April 7, 2015 ash. F Fluidal (Pele's tear-type) glass particle in the April 18-21, 2015 ash. G Very fluidal (Pele's hair-type) glass shards in the April 7, 2015 ash. H Vesiculated block-type and scoria-type glasses in February 10-25, 2015 ash. I Pele's hair-type and well-vesiculated block-type glasses in the April 7, 2015 ash

proportions of well-vesiculated glass shards increased, and both scoria type and fluidal type (Pele's tear and hair type) grains were recognized from March 17 to April 18, 2015.

\section{Discussion}

\section{Estimation of erupted tephra mass}

To estimate the tephra mass from the November 2014May 2015 activity of the Nakadake first crater of Aso Volcano, we installed ash samplers at 21 sites, including 4 sites near the crater, and calculated the mass of ashfall deposits based on 28 isomass maps. During violent volcanic activity, it was necessary to estimate eruptive mass using only distal data obtained outside a $1 \mathrm{~km}$ distance from the crater because we could not approach the crater area. The comparison between erupted mass calculated using only distal data ( $>1 \mathrm{~km}$ of crater) and calculations using both proximal (crater area) and distal data is shown in Fig. 8 and indicates that the latter values are about 1.4 times larger than those derived only from distal data; thus, the proximal eruptive masses extrapolated from distal data are significantly smaller than practically determined proximal eruptive masses. Large amounts of tephra fall not from the upper part 


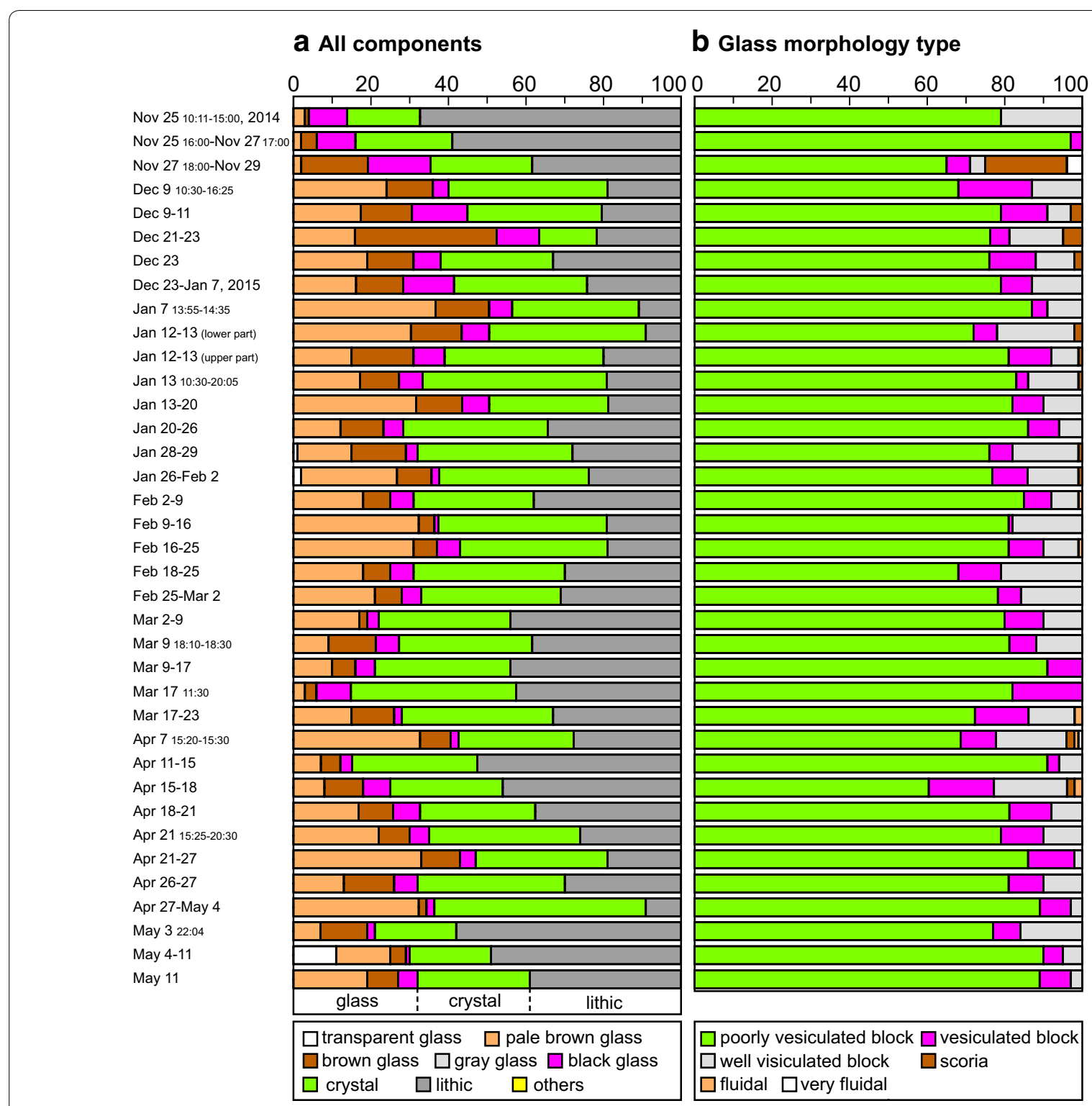

Fig. 7 Temporal variations in proportions of ash components $\mathbf{a}$ and glass types $\mathbf{b}$

but from the lower part of the tephra plume containing ash-sized particles (Mannen 2014), and a large volume of particles derived from the basal part of the tephra plume forms a pyroclastic cone (Mannen and Ito 2007). In addition, voluminous ballistic scoriaceous clasts piled up around vent 141 (Fig. 1b). Consequently, a pyroclastic cone $(120-130 \mathrm{~m}$ in diameter, $30 \mathrm{~m}$ in height as of the end of March 2015) was formed inside the Nakadake first crater by the 2014-2015 activity (Yokoo and Miyabuchi 2015). The average thickness of tephra deposits inside the Nakadake first crater was estimated to be approximately $20 \mathrm{~m}$ at the end of February 2015 (Yokoo and Miyabuchi 2015). In contrast, the thickness of tephra-fall deposits at the southwestern crater rim was approximately $25 \mathrm{~cm}$. The difference in deposit thickness between the inside and the rim of the crater suggests a possibility that even observations of tephra fall at the crater rim result in an underestimate of the erupted mass.

Figure 9 shows the percentage of deposit mass within each isomass and indicates that $30-80 \%$ of the total erupted mass is located inside the $1000 \mathrm{~g} / \mathrm{m}^{2}$ isomass, except for a few cases. Furthermore, more than $80 \%$ of the mass existed inside the $100 \mathrm{~g} / \mathrm{m}^{2}$ isomass in the case of a total deposit mass greater than 50,000 tons. The observation of tephra deposits in as many sites as possible and as frequently and as far as possible is ideal, in 


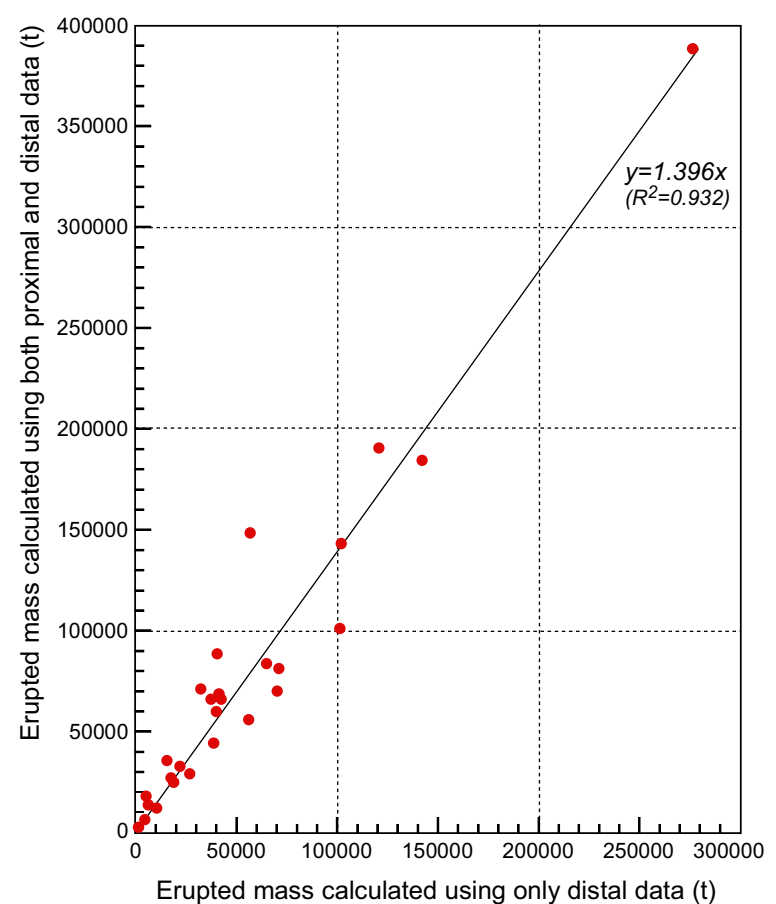

Fig. 8 Relation between erupted mass calculated using only distal data ( $>1 \mathrm{~km}$ of the crater) and calculations using both proximal (crater rim) and distal data in the case of the 2014-2015 Nakadake eruption

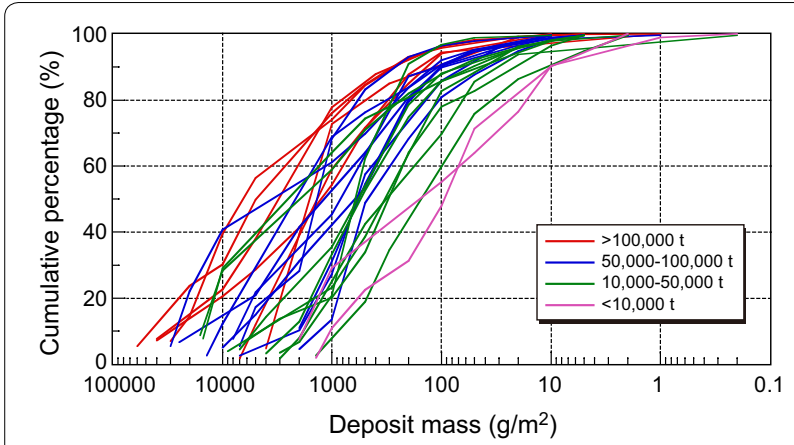

Fig. 9 Cumulative percentages of erupted mass of the 2014-2015 Nakadake ash-fall deposits

order to obtain an accurate estimate of the erupted mass; however, sampling tephra immediately after an eruption is extremely difficult. The present study demonstrates that we can estimate an erupted mass with a certain error if we conduct ash sampling inside the area that receives tephra deposits of more than $100 \mathrm{~g} / \mathrm{m}^{2}$ in the case of total deposit mass $>50,000$ tons. However, there are reports of distal fine tephra-fall deposits that make a large contribution to the total erupted mass in the case of a plinian eruption (Koyaguchi 1996; Koyaguchi and Ohno 2001). It is therefore necessary to compile and compare as much tephra-fall dispersal data as possible in order to precisely estimate the dispersal of tephra mass.

\section{Sequence of the 2014-2015 activity}

On the basis of temporal variations in the discharge rate of tephra and the components of tephra-fall deposits, the 2014-2015 eruption sequence of the Nakadake first crater is interpreted as follows:

Following the reduction in the size of the crater lake due to rising temperatures from April 2013 and the disappearance of the lake on July 12, 2014, a series of magmatic eruptions began on November 25, 2014, at the Nakadake first crater. The tephra discharge rate of the first 4 days from the onset of eruption (November 25-29, 2014) was estimated at about $3.7 \times 10^{4}$ tons/day, which was the highest rate during the November 2014-May 2015 activity. Contemporary ash-fall deposits were composed mostly of lithic fragments (59-68\%) and contained small amounts of glass shards $(<20 \%)$. Therefore, almost half of the ejecta (approximately $2.0 \times 10^{4}$ tons/day) produced in the initial stage probably originated from previously erupted materials, discharged due to the opening and enlargement of a vent inside the crater. In contrast, unaltered fresh glass shards contained in the Nakadake ash are regarded as juvenile materials originating from newly ascending magma (Miyabuchi et al. 2008, 2018; Miyabuchi and Terada 2009). Thus, we believe that magmatic materials of at least $0.8 \times 10^{4}$ tons/day corresponding to approximately $20 \%$ of the whole eruptive deposits $\left(3.7 \times 10^{4}\right.$ tons/day) were discharged in the initial stage (November 25-29, 2014). Because a fraction of all crystal grains (approximately $1.0 \times 10^{4}$ tons/day; $19-31 \%$ of the whole deposit) was derived from newly ascending magma, the magma discharge rate in the first 4 days was likely to range from $0.8 \times 10^{4}$ tons/day (only glass) to $1.8 \times 10^{4}$ tons/day (glass + crystal). In the following discussion, we will estimate magma discharge rates based only on proportions of glass shards, which provide the minimum values.

The proportions of glass particles gradually increased until the end of December 2014, and the largest rate of discharged magma during the 2014-2015 activity (approximately $1.6 \times 10^{4}$ tons/day) was recorded on December 9-11, 2014 (total mass of ash: approximately $7.0 \times 10^{4}$ tons). Subsequently, the magma discharged at the rate of $1.0 \times 10^{4}$ tons/day until the end of January $2015\left(1.3 \times 10^{4}\right.$ tons/day on January 13-20). JMA observed a gradual increase in amplitude of shortperiod tremor far before the onset of eruptive activity (from July 2014), and then, the maximum amplitude was recorded in late January 2015 (Fig. 5a). Thereafter, the amplitude gradually decreased. Short-period 
tremors observed at Aso Volcano have been classified into two types: "isolated tremor" with a dominant frequency around $1-2 \mathrm{~Hz}$ and "continuous tremor" with a dominant frequency around $3-10 \mathrm{~Hz}$ (Takagi et al. 2006). The isolated tremor occurs beneath the active crater, at a depth of several hundred meters below the ground surface, which corresponds to the upper edge of the crack-like conduit detected by Yamamoto et al. (1999) (Yamamoto 2004; Mori et al. 2008). In contrast, seismic array observations in 1999-2003 (Takagi et al. 2009) revealed that the continuous tremors during dormant periods occur at shallower depth between the upper rim of the crack-like conduit and ground surface. Ichimura et al. (2018) also concluded that the source locations of continuous tremors were distributed from the ground surface to a depth of $400 \mathrm{~m}$ beneath the crater before ash-gas emissions in January 2014. According to these observations, it is likely that the continuous tremor represents fluid flow in the uppermost conduit, and the amplitude modulation of volcanic tremor thus reflects the fluctuation in the rate of gas flux at a shallow depth (a few hundred meters below the crater) that is supplied from the underlying magma. Terada et al. (2012) practically demonstrated that the fluctuation of mass flux of high-temperature volcanic gas is consistent with those in the daily mean amplitude of short-period tremors at the Nakadake crater. In the case of Sakurajima Volcano (southern Kyushu) that frequently produces ash-fall deposits due to vulcanian and ash eruptions, a positive correlation exists between monthly weight of ash and monthly sum of seismic amplitude (particularly $2-3 \mathrm{~Hz}$ tremor) during the 2009-2013 activity (Iguchi 2016). Therefore, temporal variations in both magma discharge rate and shortperiod tremor amplitude suggest that a high rate of flux of gas and ash was maintained in the shallow conduit below at the Nakadake first crater from December 2014 to January 2015.

In addition to the increase in the proportion of glass shards, black-to-brown glass was dominant in the early stage of activity (especially until the end of November 2014), but the proportion of pale brown glass within the glass fraction gradually increased with time, so that pale brown glass predominated after mid-January 2015. The difference in glass shard color reflects varying degrees of crystallinity in glass particles. Black glass, which is highly crystallized, is likely to derive from a slow cooling outer or upper part of the magma column. In contrast, pale brown glass, which contains only rare microlites, appears to have come from a molten inner part of the conduit and resulted from rapid cooling because they are poorly crystallized (Miyabuchi et al. 2018). Therefore, the increase in proportion of pale brown glass suggests an increase in materials originating from molten inner part of the magma column.

After February 2015, both the tephra discharge rates and the proportions of glass shards decreased; thus, magma discharge rates also declined to $0.1-0.7 \times 10^{4}$ tons/day. The minimum rates were recorded at a few hundred tons/day from late March to mid-April 2015. However, strombolian eruptions intermittently occurred and scoria- and Pele's hair-type of glass shards were observed in the same period. This suggests that magma became less viscous due to an increase in magma temperature or that changes in magma composition and/or water content occurred from late March to mid-April, although the magma discharge rates were small.

From April 21 to May 4, 2015, the tephra discharge rate temporally increased, with glass shards comprising about $40 \%$. Therefore, at least $0.5-0.7 \times 10^{4}$ tons/day of magma were emitted in that period. The temporal increase in magma discharge probably led to a cavitation in the upper part of the magma column, resulting in a collapse of the crater floor, accompanied by an earthquake that was felt in the night of May 3, 2015. Although very small ash emissions occurred intermittently until the end of May 2015, magmatic activity almost ceased after the collapse event.

As mentioned above, the total erupted tephra mass of November 2014-May 2015 activity of Nakadake first crater was $2.1 \times 10^{6}$ tons $\left(1.2 \times 10^{4}\right.$ tons/day). The total mass of magma discharged was estimated at $8.2 \times 10^{5}$ tons, based on the proportion of fresh glass shards within the deposits, which are interpreted as juvenile materials. A fraction of the crystal grains was derived from newly ascending magma, and the lithic fragments also contained recycled materials that had been produced during an earlier period of the same activity; these were stored, crystallized, and altered in the crater bottom and/or inside the active vent and conduit. Therefore, the total mass of magma discharged ranged between $0.8 \times 10^{6}$ and $2.1 \times 10^{6}$ tons. The total amount of ejecta of previous active periods was reported at $3.2 \times 10^{6}$ tons in July-November 1974 (Fukuoka District Meteorological Observatory 1990), $4.6 \times 10^{6}$ tons $\left(5.2-7.9 \times 10^{4}\right.$ tons/day) in June-August 1979 (Asosan Weather Station 1980; Ono et al. 1995), $3.3 \times 10^{6}$ tons $\left(11.7 \times 10^{4}\right.$ tons/day) in November 1979 (Asosan Weather Station 1980; Ono et al. 1995), and $5.7 \times 10^{6}$ tons (4.0-5.0 $\times 10^{4}$ tons/day) in June-December 1989 (Fukuoka District Meteorological Observatory 1990; Ono et al. 1995). Therefore, the November 2014-May 2015 activity was smaller in terms of total erupted mass of tephra deposits compared to previous activity going back a few decades. 


\section{Conclusions}

Following the disappearance of the crater lake, a series of magmatic eruptions began on November 25, 2014, at the Nakadake first crater of Aso Volcano in central Kyushu, southwestern Japan, continuing until May 3, 2015. The 2014-2015 eruptive activity at Nakadake first crater was dominated by continuous ash emissions from a vent $20-30 \mathrm{~m}$ across (vent 141) formed near the center of the crater; ash emissions were accompanied by intermittent strombolian eruptions producing scoriaceous bombs from the same vent. During previous activity, strombolian eruptions occurred a few months after the beginning of the activity. In the case of the 2014-2015 magmatic activity, strombolian eruptions occurred immediately after the series of eruptions began and formed a pyroclastic cone around vent 141 by the deposition of large amounts of ash and scoria. The total erupted tephra mass of November 2014-May 2015 activity of Nakadake first crater was $2.1 \times 10^{6}$ tons $\left(1.2 \times 10^{4}\right.$ tons/day), which was smaller than those of 1974,1979 , and 1989 activities at the same crater.

The present study highlights the importance of continuous observation and sampling of tephra providing dispersal and component characteristics of eruptive deposits. These geological data are necessary to determine the magnitude and style of eruptive activity, and to elucidate the sequence and mechanism of a series of eruptions. Continuous monitoring of tephra deposits and visual observation of eruptive phenomena combined with geophysical observations would provide new insight into magmatic and eruptive processes on long-lasting activities at Nakadake Volcano and other similar basaltic to andesitic volcanoes.

\section{Additional files}

Additional file 1. Isomass maps for each sampling period from November 25, 2014 to May 25, 2015. The numerals show the weight per unit area $\left(\mathrm{g} / \mathrm{m}^{2}\right)$.

Additional file 2. Mass of tephra discharged and isomass area for each sampling period during the November 2014-May 2015 activity of Nakadake first crater.

\section{Authors' contributions}

YM carried out field surveying and ash sampling, data processing, drawing the distribution maps, and calculating discharged masses of ash-fall deposits. $\mathrm{CH}$ observed thin sections of ash samples. All authors read and approved the final manuscript.

\section{Author details}

${ }^{1}$ Faculty of Advanced Science and Technology, Kumamoto University, Kurokami 2-40-1, Chuo-ku, Kumamoto 860-8555, Japan. ${ }^{2}$ Earthquake Research Institute, The University of Tokyo, 1-1-1 Yayoi, Bunkyo-ku, Tokyo 113-0032,
Japan. ${ }^{3}$ Nishikokubu Elementary School, 1972-1 Suwanomachi, Kurume, Fukuoka 830-0037, Japan.

\section{Acknowledgements}

Parts of fieldwork were undertaken with Hideho Inoue, Daiji Goto, Akihiko Yokoo, Mitsuru Utsugi and Takahiro Ohkura. They provided us valuable information on recent activity of Nakadake first crater and suggested their interpretation. The Aso Summit Office (Aso City) helped our field survey. Ash sampling was supported by Tohru Ogata, Risa Kuwata, Akina Takahashi, Kyohei Kubota, Arata Ichihara, Tsukiko Higashi, and Mariko Hisanaga. Discussions with Nobuo Geshi and Hideo Hoshizumi concerning the ash-fall deposits and activity of Nakadake first crater were very helpful. We thank Mare Yamamoto for providing invaluable advice on volcanic tremors at Nakadake crater. The manuscript was improved by constructive comments from two anonymous reviewers. The editorial assistance of Takahiro Ohkura is also acknowledged. This paper is dedicated to the memory of our wonderful colleague Yasuaki Sudo who researched the activity of Aso Volcano for over 50 years.

\section{Competing interests}

The authors declare that they have no competing interests.

\section{Availability of data and materials}

The datasets used and/or analyzed during the current study are available from the corresponding author on reasonable request.

\section{Funding}

This study was supported by the Ministry of Education, Culture, Sports, Science and Technology (MEXT) of Japan, under its Earthquake and Volcano Hazards Observation and Research Program (No. 1802).

\section{Publisher's Note}

Springer Nature remains neutral with regard to jurisdictional claims in published maps and institutional affiliations.

Received: 7 November 2018 Accepted: 21 March 2019

Published online: 15 April 2019

\section{References}

Andronico D, Scollo S, Caruso S, Cristaldi A (2008) The 2002-03 Etna explosive activity: Tephra dispersal and features of the deposits. J Geophys Res Solid Earth 113:B005126

Asosan Weather Station (1980) 1979 activity of Aso Volcano. Report of Coordinating Committee for Prediction of Volcanic Eruption 17, pp 17-20 (in Japanese)

D'Oriano C, Bertagnini A, Pompilio M (2011) Ash erupted during normal activity at Stromboli (Aeolian Islands, Italy) raises questions on how the feeding system works. Bull Volcanol 73:471-477

Fierstein J, Hildreth W (1992) The plinian eruptions of 1912 at Novarupta, Katmai National Park, Alaska. Bull Volcanol 54:646-684

Fukuoka District Meteorological Observatory (1965) Eruptive history of Aso Volcano. Mem Fukuoka Dist Meteorol Obs 20:15-46 (in Japanese)

Fukuoka District Meteorological Observatory (1990) Volcanoes in Kyushu: Aso Volcano. Mem Fukuoka Dist Meteorol Obs 45:1-46 (in Japanese)

Fukuoka District Meteorological Observatory (2015) Volcanic regular bulletin of Aso Volcano in 2014. 21 pp (in Japanese)

Fukuoka District Meteorological Observatory (2016) Volcanic regular bulletin of Aso Volcano in 2015. 31 pp (in Japanese)

Ichimura M, Yokoo A, Kagiyama T, Yoshikawa S, Inoue H (2018) Temporal variation in source location of continuous tremors before ash-gas emissions in January 2014 at Aso Volcano, Japan. Earth Planets Space 70:125. https ://doi.org/10.1186/s40623-018-0895-4

Iguchi M (2016) Method for real-time evaluation of discharge rate of volcanic ash-case study on intermittent eruptions at the Sakurajima volcano, Japan. J Disaster Res 11:4-14

Iguchi M, Tameguri T, Ohta Y, Ueki S, Nakao S (2013) Characteristics of volcanic activity at Sakuraijma volcano's Showa crater during the period 2006 to 2011. Bull Volcanol Soc Jpn 58:115-135 
Ikebe S, Watanabe K, Miyabuchi Y (2008) The sequence and style of the 1988-1995 eruptions of Nakadake, Aso Volcano, Kyushu, Japan. Bull Volcanol Soc Jpn 53:15-33 (in Japanese with English abstract)

Koyaguchi T (1996) Volume estimation of the ejecta of Pinatubo 1991 eruption by means of fluid dynamics model and geological methods. In: Newhall CG, Punongbayan R (eds) "Fire and Mud" monograph of the Pinatubo 1991 eruption, pp 583-600

Koyaguchi T, Ohno M (2001) Reconstruction of eruption column dynamics on the basis of grain-size of tephra-fall deposits: part 2. Application to the Pinatubo 1991 eruptions. J Geophys Res 106:6513-6533

Mannen K (2014) Particle segregation of an eruption plume as revealed by a comprehensive analysis of tephra dispersal: theory and application. J Volcanol Geotherm Res 284:61-78

Mannen K, Ito T (2007) Formation of scoria cone during explosive eruption at Izu-Oshima volcano, Japan. Geophys Res Lett 34:L18302

Miwa T, Geshi N, Shinohara H (2013) Temporal variation in volcanic ash texture during a vulcanian eruption at the Sakurajima volcano, Japan. J Volcanol Geotherm Res 260:80-89

Miyabuchi Y (2009) A 90,000-year tephrostratigraphic framework of Aso Volcano, Japan. Sed Geol 220:169-189

Miyabuchi Y, Ikebe S (2008) The February 2008 ash deposit from the Nakadake crater, Aso Volcano, Japan. Bull Volcanol Soc Jpn 53:201-206 (in Japanese with English abstract)

Miyabuchi Y, Terada A (2009) Subaqueous geothermal activity revealed by lacustrine sediments of the acidic Nakadake crater lake, Aso Volcano, Japan. J Volcanol Geotherm Res 187:140-145

Miyabuchi Y, Hoshizumi H, Takada H, Watanabe K, Xu S (2003) Pumice-fall deposits from Aso Volcano during the past 90,000 years, southwestern Japan. Bull Volcanol Soc Jpn 48:195-214 (in Japanese with English abstract)

Miyabuchi Y, Hoshizumi H, Watanabe K (2004) Late-Pleistocene tephrostratigraphy of Aso Volcano, southwestern Japan, after deposition of AT ash. Bull Volcanol Soc Jpn 49:51-64 (in Japanese with English abstract)

Miyabuchi Y, Ikebe S, Watanabe K (2008) Geological constraints on the 2003-2005 ash emissions from the Nakadake crater lake, Aso Volcano, Japan. J Volcanol Geotherm Res 178:169-183

Miyabuchi Y, Hanada D, Niimi H, Kobayashi T (2013) Stratigraphy, grain-size and component characteristics of the 2011 Shinmoedake eruption deposits, Kirishima Volcano, Japan. J Volcanol Geotherm Res 258:31-46

Miyabuchi Y, lizuka Y, Hara C, Yokoo A, Ohkura T (2018) The September 14, 2015 phreatomagmatic eruption of Nakadake first crater, Aso Volcano, Japan: Eruption sequence inferred from ballistic, pyroclastic density current and fallout deposits. J Volcanol Geotherm Res 351:41-56

Mori T, Sudo Y, Tustsui T, Yoshikawa S (2008) Characteristics of isolated hybrid tremor (HBT) during a calm activity period at Aso Volcano. Bull Volcanol 70:1031-1042

Nakamura M (2002) The change in volume of volcanic ash-fall deposits erupted from Sakurajima Volcano. Q J Seismol 65:135-143 (in Japanese)

Ohkura T (2018) Eruptive style of Aso Volcano: implication from magma intrusion rate. Japan Geoscience Union Meeting 2018 Abstract: SVC41-07

Ohsawa S, Saito T, Yoshikawa S, Mawatari H, Yamada M, Amita K, Takamatsu N, Sudo Y, Kagiyama T (2010) Color change of lake water at the active crater lake of Aso Volcano, Yudamari, Japan: is it in response to change in water quality induced by volcanic activity? Limnology 11:207-215

Oishi M, Nishiki K, Geshi N, Furukawa R, Ishizuka Y, Oikawa T, Yamamoto T, Nanayama F, Tanaka A, Hirota A, Miwa T, Miyabuchi Y (2018) Distribution and mass of tephra-fall deposits from volcanic eruptions of Sakurajima Volcano based on posteruption surveys. Bull Volcanol 80:42

Ono K, Watanabe K (1985) Geological map of Aso Volcano 1:50,000. Geological Map of Volcanoes 4, Geological Survey of Japan (in Japanese with English abstract)

Ono K, Shimokawa K, Soya T, Watanabe K (1982) Geological and petrological study on the ejecta of 1979 eruption of Nakadake, Aso Volcano, Japan. Report on an urgent study of 1979 Eruption of Ontake and Aso Volcano. Science and Technology Agency, pp 167-189 (in Japanese)

Ono K, Watanabe K, Hoshizumi H, Ikebe S (1995) Ash eruption of the Nakadake crater, Aso Volcano, southwestern Japan. J Volcanol Geotherm Res $66: 137-148$

Shimano T, Nishimura T, Chiga N, Shibasaki Y, Iguchi M, Miki D, Yokoo A (2013) Development of an automatic volcanic ash sampling apparatus for active volcanoes. Bull Volcanol 75:773

Taddeucci J, Pompilio M, Scarlato P (2002) Monitoring the explosive activity of the July-August 2001 eruption of Mt. Etna (Italy) by ash characterization. Geophys Res Lett 29:1230

Takagi N, Kaneshima S, Kawakatsu H, Yamamoto M, Sudo Y, Ohkura T, Yoshikawa S, Mori T (2006) Apparent migration of tremor source synchronized with the change in the tremor amplitude observed at Aso Volcano, Japan. J Volcanol Geotherm Res 154:181-200

Takagi N, Kaneshima S, Ohkura T, Yamamoto M, Kawakatsu H (2009) Long-term variation of the shallow tremor sources at Aso Volcano from 1999 to 2003. J Volcanol Geotherm Res 184:333-346

Taneda S, Matsumoto Y, Miyachi S, Miyachi M, Ishibashi K, Kojima M (1959) The 1958 June eruption of volcano Aso. Bull Volcanol Soc Jpn 3:136-146 (in Japanese with English abstract)

Terada A, Hashimoto T, Kagiyama T, Sasaki H (2008) Precise remote-monitoring technique of water volume and temperature of a crater lake in Aso Volcano, Japan: implications for a sensitive window of a volcanic hydrothermal system. Earth Planets Space 60:705-710. https://doi.org/10.1186/ BF03353134

Terada A, Hashimoto T, Kagiyama T (2012) A water flow model of the active crater lake at Aso Volcano, Japan: fluctuations of magmatic gas and groundwater fluxes from the underlying hydrothermal system. Bull Volcanol 74:641-655

Watanabe K (1991) Volcanic activity of Nakadake, Aso Volcano. J Kumamoto Geosci Assoc 98:2-13 (in Japanese)

Yamamoto M (2004) Volcanic fluid system inferred from broadband seismic signals. PhD thesis, University of Tokyo, Japan

Yamamoto M, Kawakatsu H, Kaneshima S, Mori T, Tsutsui T, Sudo Y, Morita Y (1999) Detection of a crack-like conduit beneath the active crater at Aso Volcano, Japan. Geophys Res Lett 26:3677-3680

Yokoo A, Miyabuchi Y (2015) Eruption at the Nakadake 1st crater of Aso Volcano started in November 2014. Bull Volcanol Soc Jpn 60:275-278 (in Japanese)

\section{Submit your manuscript to a SpringerOpen ${ }^{\circ}$ journal and benefit from:}

- Convenient online submission

- Rigorous peer review

- Open access: articles freely available online

- High visibility within the field

- Retaining the copyright to your article

Submit your next manuscript at springeropen.com 